\title{
Renunciation and Non-Renunciation in Indian Films
}

\author{
Pankaj Jain*
}

North Carolina State University

\begin{abstract}
Renunciation is one of the most widely studied subjects among Indic traditions. The image of a half-naked ascetic with a stick in one hand and a begging bowl in other has captured the attention of scholars more often than the mundane householder. Whereas the ascetic captured the imagination with his (and sometimes her) individualistic spirit rebelling against the maligned caste hierarchy, the householder has been seen as a poor creature living a routine life according to the rules dictated by the caste (varna) and the stage in life (ashrama). In this article, I review several films to analyze the portrayal of ascetics and householders, but cannot claim that the review is encyclopedic because there are so many films with variations on this theme. All of the films introduced here were made by Indian filmmakers except for two Hollywood films, ${ }^{1}$ The Householder (1963) and Siddhartha (1972), that were filmed in India with an Indian cast and story.
\end{abstract}

\section{Non-Renunciation in The Householder (1963) and in Yehi Hai Zindagi (1977)}

T. N. Madan (1987) lists a number of medieval and contemporary movements with millions of followers in India. All of them have emphasized the virtues of disciplined domesticity as against renunciation, for instance, Basava (1125-1270?), the founder of Lingayat sect in the South, Nanak (1469-1538), the first Sikh gurus in the North, Vallabha (14791531), the promulgator of the Pushti Marga in the West, and Chaitanya (1485-1534), founder of a Vaishnava sect in the East. All extolled domesticity as the good life as long as it was an affirmation of the bliss of the union of the devotee and the deity, and not a contradiction of it. Similarly, one of the most important Hindu texts Manu Smriti says: 'Because men of the three other orders (studentship, retirees, and ascetics) are daily supported by the householder with gifts of sacred knowledge and food, therefore, the order of householder is the most excellent order' (3.78). Further, the importance of marriage and householder life is strongly recommended in the same text: 'When, unswerving in his chastity, [the student] has learned the Vedas, or two Vedas, or even one Veda, in the proper order, he should enter the householder stage of life' (3.2). In general, most classical Indian texts highlight the importance of the householder stage of life over other stages and even incorporate the ideals of other stages within the householder stage without abandoning the family. ${ }^{2}$

Despite this importance given to the householders in the Hindu texts and movements, few films have explored the life of a householder in Hindu milieu. The Merchant-Ivory debut film, The Householder (1963) fills this gap in a delicate and humorous manner. Prem and Indu have just entered an 'arranged' married and are still virtually unknown to each other. Prem (played by Shashi Kapoor) is distressed with his new wife and with his supervisors at the local college where he teaches. Thus, the twin duties of the householder, pursuing a career and raising a family, are both explored in the early part of the film. Prem initially has trouble accepting his new wife Indu and seeks guidance from his 
friend, mother, and even a religious guru. But once Indu leaves his house in her pregnancy, soon the 'cold ice' between them melts and they eventually unite as happy husband and wife. One of the unique features of Hindu society, 'arranged marriage' is explored sympathetically and sensitively in the film, and the development of characters nicely captures the subtleties of newlywed couple. Also shown is the powerful and controversial role of a mother-in-law in traditional South Asian communities. Now that urban India is losing such social customs, the film provides a rare at them. Interestingly, Prem's interactions with a local ascetic eventually turn him back to his householder life, thus showing the contrast between the two modes of Hindu life. Unlike this happy ending, in Sara Akash (1969) a Hindu husband rebels against his 'arranged marriage' and abandons his wife. The story of Sara Akash was written by Rajendra Yadav in 1951, and the story of The Householder was written in 1960 by Ruth Prawer Jhabvala - under the influence of Yadav's story.

Unlike the brief look at the early householder life of Prem and Indu in The Householder, the Hindi film Yehi Hai Zindagi (1977) offers a much longer duration of another Hindu family headed by the patriarch Anand Narayan (played by Sanjeev Kumar who devoted large part of his career playing the roles much older than his real age). While renunciation attracts some people for its spiritual rewards, householder life may attract others for its materialistic rewards. Anand is one such individual whose only goal in life is to overcome poverty and achieve material success. Miraculously, Lord Krishna visits Anand, blesses him, and fulfills his desire. This dramatic boon changes Anand's life, and his small food shop emerges into a fine restaurant and eventually into a five-star hotel. This also reflects in the luxurious mansion that Anand's family moves into from their older dilapidated house. Immensely proud of his new life, Anand denies any divine role or boon in his success. However, his successful life turns sour when his partner and his son's father-in-law Nekiram cheat him. Anand is soon left alone when Nekiram, Nekiram's daughter, and her husband (Anand's son) all leave his family. As if this were not enough, Anand finds out that his second son is now ruined by vices and addictions that sometimes affect the nouveau riches, and Anand's daughter gets pregnant before marrying her boyfriend. Unable to bear such shocks, his health deteriorates and he becomes dependent on all kinds of medicines for survival. Thus, material success turns into disaster on many fronts. Lord Krishna visits again and asks about his well-being and the names of medicines. As most of his medicine-names end with 'cin' (rhyming with the word medicine), Krishna tells Anand that these are his 'sins' that are hounding him now. The film ends with the Hindu teaching that in householder life the pursuit of wealth and pleasure must be under the laws of Dharma and Karma. Krishna reiterates Bhagvad Gita's message in the film that one must act without attachment to the fruits of action. The ego must be surrendered to God to achieve the right balance of action and non-action (renunciation).

\section{Renunciation of Siddhartha (1972), Jogan (1950), Chitralekha (1964), and Trishagni (1994)}

Siddhartha (1972) is a film based on the German novella by Hermann Hesse (1922) with the same title. It is set in the times of Asia's most renowned ascetic, the Buddha. As is well-known Siddhartha was also one of the earlier names of the Buddha before he renounced his family and his kingdom. However, Siddhartha of the novel and film is neither born in a princely state nor lives to become a Buddhist monk as his name might suggest. Although film's director claimed that the film has a Buddhist message, I argue that the story actually criticizes the ascetic traditions of Buddhism and other similar renunciatory traditions. Although Siddhartha is in search of enlightenment and renounces 
family early in his life, he remains unsatisfied with his ascetic sojourns and his colleagues. His old friend Govinda formally joins the Buddha's Sangha, but Siddhartha leaves the ascetic life when he chances upon the courtesan Kamala who promises to teach him the art of love. The former ascetic indulges in sensual pleasure and later becomes father of a son. To be able to support this new life, Siddhartha starts working for a rich trader and eventually becomes one himself. Remarkably, he maintains equanimity without getting carried away by the worldly pleasures. However, after few years Siddhartha is disillusioned with this new life. Once again, he renounces his home and goes to the forest. Reaching the same river that he had visited in his early life, he meets the boatman Vasudeva (a synonym of Lord Krishna) that he had met before. There Siddhartha finally attains enlightenment. He learns that deepest knowledge is neither to be gained from pure asceticism nor from worldly pleasures, but by being able to listen to the river. The continuity of the river teaches him the circle of life. In Hindu myths, divinity is often called a boatman - someone who helps the devotees cross the Bhavsagar or ocean of repeated lives and deaths - and this boatman helps Siddhartha in a similar way. In the climactic scenes, he bears the loss of his family when Kamala dies and their son leaves Siddhartha, too.

While Siddhartha was the tale of a male Brahmin's trials and tribulations with ascetic and householder modes of life, Jogan (1950) was a rare Hindi film in which, as the title signifies, a female mendicant's struggle with celibacy was brilliantly portrayed. After the death of her father, Surabhi renounces the worldly life to escape from her brother who wanted to marry her off to an old man. Early in the film, she suffers unwelcome visits from the atheist Vijay. When she is not able to stop Vijay from visiting her, she moves out of the village and forbids Vijay from following her beyond a certain tree outside the village. A colleague of Surabhi later gives Vijay a book that was written by Surabhi, and at last Vijay visits the memorial built at the death site of Surabhi who had been unable to resist temptations by Vijay and so committed suicide after leaving Vijay's village.

The filmmaker Kidar Nath Sharma, who made Jogan, chose a similar story to make Chitralekha twice in 1941 and in 1964. That is a story adapted from a 1934 Hindi novel by Bhagwati Charan Verma (1994). It is yet another story of a courtesan in a semi-historic setting of third century emperor Chandragupta Maurya in Northern India. As the love between the courtesan Chitralekha and Bijagupta, who serves in the emperor's court, begins to flourish, a hermit Kumaragiri is employed to thwart their budding relationship. Ironically, the ascetic becomes obsessed by Chitralekha's charm and eventually commits suicide as the only resolution to his temptations - like Jogan's tragic end. Bijagupta and Chitralekha both are filled with remorse and leave their town separately. Later, they unite again but by then Bijagupta is an ascetic and Chitralekha becomes his disciple.

Like Chitralekha, Amrapali (1966) is a film also adapted from a semi-historical Hindi novel by Acharya Chatursen. It had been done in 1945 in an earlier Hindi film and in 1959 in a Bengali film. This is yet another story of a courtesan, Amrapali, who develops a romantic relationship with Ajatshatru, the emperor of Magadh, a major ancient Indian kingdom. Ajatshatru invades the city of Vaishali to expand his empire but is defeated, is sheltered by Amrapali as a disguised Vaishali soldier, and then escapes. Both had fallen in love, and Amrapali is arrested when her affair with the enemy is found out. When he learns about Amrapali's arrest, Ajatshatru invades Vaishali again, this time successfully. Meanwhile Amrapali had a spiritual experience by meeting the Buddha. Legend has it that the Buddha accepted food from her, a courtesan, against social convention. Now a Buddhist, instead of accepting Ajatshatru, she criticizes the futility of war (Chatursen 1985). 
Angulimala (1960) is another semi-historical film that is set in the time of the Buddha. It was made by an Indian director with the help from a Thailand based company. A similar film in Thai language was released in 2003. Both films are based on the legend of a murderer who is destined to kill one thousand people and to wear their fingers as his necklace - hence his name (Anguli - finger, Mal - chain). Finally, he has an encounter with the Buddha and becomes a Buddhist monk, proving that his original name Ahinsak (meaning non-violent) was accurate.

In Trishagni there is a similar struggle by Buddhist monks with lust and greed. In a central Asian desert town two monks are living after the death of the Buddha. In a sandstorm, the whole village sinks, but the monks Pitumita and Uchanda succeed in escaping. After the storm, they find a boy Nirvana and a girl Ethi. After many years, Uchanda is lured by the girl who has now become a young and beautiful woman and has fallen in love with the boy who grew up with her also at the monastery. Enraged by lust and jealousy, Uchanda tries to separate them, makes Nirvana a monk, advises him that not to have any relation with opposite sex, and eventually banishes the two in another sandstorm only to repent his action later. Misused or corrupt celibacy was also the subject in Samskara (1970) and Diksha (1991), both based on published stories by U. R. Anantha Murthy (1976). Similarly, Jaadugar (1989) and Swami Dada (1982) exposed corrupt ascetics who cheated their disciples in different ways while Sanyasi (1975) made a mockery of an orthodox Hindu celibate and Paap (2003) portrayed a Buddhist nun-to-be who fell in love with a police officer.

The Buddha's biography, however, is rarely portrayed in Indian films. An early attempt was a silent film Prem Sanyas (aka the Light of Asia; 1925) which was an Indian and German collaboration. Another is a documentary Gautama the Buddha (1967), and there was a TV series titled Buddha. However, other influential historic Hindu ascetics have given rise to several Indian films. Shankaracharya was portrayed in two silent versions in 1927 and 1928, one Hindi version in 1955, and most famously in the world's first Sanskrit film Adi Shankaracharya (1983) made by G. V. Iyer. In 1987, Iyer made a Kannada film on the life and works of another major ascetic figure, Madhvacharya (1987). Similarly, Swami Vivekananda (1949), the Hindu monk who became famous after his 1893 Chicago speech to the World's Parliament of Religions, was depicted in films in 1955 and in 1994 (Vivekananda 1994). However, there are no films about any Jain ascetics. Although Rachel Dwyer (2006, p. 141) mentions that the protagonist Adinath in Do Ankhen Barah Haath (1957) has a Jain name, it could equally well be a Hindu name as Adinath is not only the name of the first Jain enlightened figure but also a name of the Hindu god Shiva.

Socio-Political Renunciation of Anandmath (1952), Shaheed (1965), Devdas (1955), Saraswatichandra (1968), and Guide (1965)

Some readers might be surprised by my inclusion of these films that have little or no spiritual or religious theme but in all these films, the leading male characters resort to celibacy for various reasons. Vijay Mishra has also alluded to 'the power of the renouncer' in several films in his study (Mishra 2002, p. 6). He notes several instances in which the renouncer hero's independence from society provides him enormous power of action. I provide some such examples below.

Anandmath (1952) is based on a novel by Bankimchandra Chattopadhyaya (2005) about the early political rebellion against the British which is sometimes called as the "Sannyasi Rebellion'. 3 This is perhaps the only major film in which a group of ascetics conduct 
their battle against the British using unconventional strategies and weapons. More than the film, one of the songs from the film has emerged as India's national song, ritually played on India's Independence Day and other national holidays.

Shaheed (1965) is based on the life of famous Indian freedom fighter Bhagat Singh. In contrast to the religious ascetics of Anandmath, Bhagat Singh had famously written 'Why I am an Atheist?' (Singh 1930). He espoused Marxist ideology and launched one of the most active anti-British campaigns in late 1920s British India before he was hanged on March 23rd, 1931. ${ }^{4}$ In addition to Bhagat Singh's patriotic activities, he is also remembered for his steadfast celibacy, and the 1965 film and other versions prominently display his insistence on denying his parental wishes and the pleasure of family life. For instance, in one of the scenes in Shaheed, when his mother shows him the jewelry of his potential wife, he immediately stands up and tells her that he is already 'married to the bride of national freedom.' In the climactic scene, he sacrifices his life to the cause of his nationalistic 'marriage.' His celibacy thus turns nihilistic albeit for a higher cause and ignites the revolutionary spirit across the nation.

Unlike Bhagat Singh's celibacy with the higher goal of nationalism, celibacy in the film Devdas (1955) is a tragic narrative. The title character is a lover whose desire for Paro, his childhood girlfriend, remains unfulfilled until his death. Paro lives in his neighborhood in their village, but her family is of a lower social class and thus their budding romance is thwarted. But undaunted Paro, in a rare example of a feminine agency in Indian films, comes to Devdas in the middle of the night and asks him to escape the society and consummate their love. It is Devdas who shrinks from this rebellious drive and asks Paro to go back to her house. This one action hounds him throughout his life. He leaves his village to go to Calcutta (now called Kolkata) where a friend takes him to a prostitute. Here again, it is a prostitute Chandramukhi who falls in love with him, but he fails to accept her because his heart is still with Paro. Ultimately, his depression leads him to narcissistic addiction to alcohol. Trying to fulfill a promise to Paro to see her once again, he makes a train journey across the country to reach Paro's house. Meanwhile Paro already has been married to a rich widower landlord as a reaction to the rejection from Devdas's family. In the climactic scene, Devdas is on his last breath and Paro runs to see him for the last time, but once again society's rules close all 'gates' and prevents their union once again. Devdas dies alone outside Paro's house.

A similar but rarely discussed film is Saraswatichandra (1969). While the legends of Bhagat Singh and Devdas, historical and mythical respectively, have been captured by scores of Indian films (for a comparative study of different Devdas versions see Creekmur 2007, pp. 173-90), the legend of Saraswatichandra has not found many takers. Devdas was written in Bengali in 1917 by legendary Bengali litterateur Sharatchandra Chattopadhyaya. It was soon translated into many Indian languages, and with several films based on this novella in different Indian languages, it continues its vogue in the 21 st century. As recently as 2002, Devdas found himself in new incarnations, for instance in a Bollywood blockbuster and a new English translation (Chattopadhyaya \& Guha 2002). Compared with this long career of Devdas, Saraswatichandra remains an obscure name for most film scholars and fans. While Devdas was played by the widely known Bollywood actor Shahrukh Khan and thus enjoyed a global recognition, Saraswatichandra was made only once in a black-and-white film in 1969. Although the DVD was released recently, today it is available only in a dozen academic libraries in the world. ${ }^{5}$ What is most interesting about Saraswatichandra is that it was written several years before Devdas was written. Unlike the novella Devdas, Saraswatichandra was an 'epic' written in Gujarati by Govardhanram Madhavram Tripathi (2007) in four volumes ranging more than 1,350 
pages. The first volume came out in 1887 and the last one in 1902, each divided chronologically, tracing the hero Saraswatichandra's life, romance, and the ultimate renunciation of the heroine Kumud. Somewhat ironically, in its 1969 Hindi film incarnation, the film is more remembered for the powerful performance of Nutan who played the character of Kumud. The fateful relationship of Kumud and Saraswatichandra is what seems to have found another glimpse in the form of Devdas and Paro in the Bengali novella and the film(s) Devdas.

Like Devdas, the plot of Saraswatichandra also starts with two families. Saraswatichandra is born in one of these families, is well-versed with Sanskrit and English literature, is a lawyer by his professional training, and also helps his father in his business in Bombay (now Mumbai). Saraswatichandra loses his mother and is later ill-treated by his stepmother. The second family is headed by someone who enjoys a high political rank in the local court and is a father of two daughters Kumud and Kusum. Saraswatichandra and Kumud are engaged to be married and upon exchanging letters (and an accompanying Hindi song in the film) fall in love. Meanwhile, Saraswatichandra's father gets deluded by his new wife who forces Saraswatichandra to renounce his home. He travels to a new city where by the turn of the events, Kumud is married to somebody else. What is more, Saraswatichandra finds himself a guest at Kumud's new married home. As the old love between them is just about to be rekindled, he is once again forced to leave this city even as Kumud is also paying a visit to her mother at another town. On his way, Saraswatichandra is attacked by robbers, and just before Kumud is to be attacked, her relatives foil the attack. Kumud jumps into a nearby river to avoid social embarrassment and is assumed to be dead. Coincidentally, Saraswatichandra and Kumud are rescued by ascetics and once again meet each other in a third new location. Although Kumud has now become widow, she resists being married to Saraswatichandra, and forces him to marry her younger sister Kusum. Although it is Saraswatichandra who tries to become an ascetic earlier in the story, it is Kumud who finally becomes an ascetic in the climactic scene as a tragic result of her widowhood.

A discerning reader may already have noticed the parallels found in Devdas written decades later in a different South Asian language. In both the stories, the male protagonists appear on the titles of the films (and the original novels) and lead the stories. However, they can never overcome their indecisiveness under the pressures from their immediate families and larger society. They remain celibate for most of the story while traveling from one place to another. Of course, the differences are also stark differences between these stories. While Kumud, the heroine of Saraswatichandra, eventually appears as a strong force making tough decisions about her life and of her ex-lover, women of Devdas fail to change their destinies and of their lover. The biggest difference in the two stories is their portrayal of celibacy. While the celibacy of Devdas is an escapist's fare of a man broken in his spirits, the celibacy of Saraswatichandra is initially a quest for higher goals, and finally that goal is transferred to Kumud when she decided to become an ascetic, partly as a result of her new widowhood. Despite these differences, the common thread running through both the stories is social pressures playing down heavily on individual lives. Celibacy provides an easy way out to escape this torment. Thus, we find that celibacy in some films (and even in real life) can be simply an outcome of socio-political circumstances. Renunciation might not be inspired by religious reasons alone as the life of Bhagat Singh and legends of Devdas and Saraswatichandra demonstrate to us.

Another important film in this genre that I would like to include is Guide (1965). This is a film adapted from an English novel by prolific author R. K. Narayan (1958). It is a 'progressive' story of a woman who abandons her abusive husband and joins a tourist 
guide Raju to become a famous dancing star. By a turn of the events, Raju is charged in a forgery case and ends up in prison. After release from his imprisonment, he is received by innocent villagers who make him an ascetic and ask him to pray for the droughtstricken village. Raju becomes a revered Swami of the community and when the monsoon rain does arrive, the villagers are overjoyed but Raju is so frail from his long fast that he dies. In the final scene, there is a debate between the mortal body and the immortal soul of Raju. Thus, a small guide, unexpectedly forced to become an ascetic, eventually rises to the highest spiritual stage.

\section{Conclusion}

What can be the conclusion of reviewing several seemingly different films some of which were adapted from classic novels, novellas, and epics in different languages and regions? One common thread that emerges from these films is that renunciation by itself is rarely treated as 'holier than thou' concept in these films. Ascetics more typically are seriously questioned and critiqued about their motives and conduct vis-à-vis larger society. Some films simply apply asceticism in the service of other socio-political goals and others portray it as an escapist route. Such critique of renunciation is captured by Olivelle (2003) by citing these words of the ex-Vice-President of India, B. D. Jatti:

Who is better - the householder or the sanyasi? Of course, the householder. While the householder willingly renounces all that he earns to his wife and children for their love and affection, the sanyasi depends on others for his milk and fruits. Parasites, who are a mere burden on society, are sinners. If man has to progress, everybody has to work. (Indian Express, May 8, 1978)

\section{Short Biography}

Pankaj completed his BS (Computer Engineering) from Karnataka University, MA (Indian Religions) from Columbia University, and $\mathrm{PhD}$ (Indian Religions and Ecology) from the University of Iowa. Currently, he is a Teaching Assistant Professor at North Carolina State University where he is teaching Indic Traditions and Ecology, Indian Films, Hinduism, Jainism, Sanskrit, and Hindi/Urdu languages and literatures. He has also taught at Rutgers, Kean, New Jersey City University, and University of Iowa. He is interested to connect ancient traditions with contemporary issues which he dealt with in his dissertation 'Indic Traditions and Ecology.' He has published portions from his research in journals such as Religious Studies Review, Worldviews, and Visual Anthropology and is currently working on his monograph Dharma and Ecology.

\footnotetext{
Notes

* Correspondence address: Dr Pankaj Jain, Department of Foreign Languages and Literatures, North Carolina State University, Raleigh, NC 27695, USA.E-mail: pjain5@ncsu.edu.

1 There are numerous Hollywood films made on similar themes of asceticism in Christianity which are beyond the scope of this article, for instance, Scarlet Letter (1995) and I Confess (1953). I also have not included an Indian film Sins (2005) which was about a Christian priest. Also excluded are other Hollywood comedies such as The Guru (2002) and The Love Guru (2008).

2 See Jain 2006 for a historical overview of this tension between the stages of householders and ascetics in Indian traditions.

${ }^{3}$ See Pinch 2006 for a book-length study of hitherto unknown ascetic rebellion in colonial India.
} 
4 Coincidentally, March 23rd was also the date when American freedom fighter Patrick Henry gave the speech with his famous slogan 'Give me Liberty, or give me Death' and Bhagat Singh lived just such a life!

5 http://www.worldcat.org/search?qt=worldcat_org_dvv\&q=saraswatichandra\&fq $=\mathrm{fm} \% 3 \mathrm{Advv}$ (this list gives at least an approximate trend for availability of Saraswatichandra compared with ubiquity of Devdas.

\section{Works Cited}

\section{BIBLIOGRAPHY}

Chatursen, Acharya. (1985 [1948]). Vaishali ki Nagarvadhu. New Delhi: Rajpal and Sons.

Chattopadhyaya, Sharatchandra \& Guha, Shreejata (2002). Devdas: A Novel. New Delhi: Penguin Books.

Chattopadhyaya, Bankimchandra (2005 [1882]). In: Julius Lipner (ed.), Annandamath, or, The sacred brotherhood. New York: Oxford University Press.

Creekmur, Corey (2007). Remembering, Repeating, and Working through Devdas. In: Heidi R. M. Pauwels (eds.), Indian Literature and Popular Cinema: Recasting Classics. New York: Routledge.

Dwyer, Rachel. (2006). Filming the Gods: Religion and Indian Cinema. London: Routledge.

Hesse, Hermann. (1922 [1951]). Siddhartha: An Indian Tale. New York: Bantam Books.

Jain, Pankaj. (2006). Householders and Renouncers, The Holistic Combination in Indian Thought. In: P. George Victor and V. V. S. Saibaba (eds.), Studies in Vedanta: Essays in Honor of S. S. Rama Rao Pappu, pp. 165-180. New Delhi, D. K. Printworld.

Madan, T. N. (1987). Non-Renunciation: Themes and Interpretations of Indian Culture. Delhi: Oxford University Press. Mishra, Vijay. (2002). Bollywood Cinema: Temples of Desire. New York: Routledge.

Murthy, Anantha U. R. (1976 [1966]). Samskara: A Rite for a Dead Man. Delhi: Oxford University Press.

Narayan, R. K. (1958). The Guide. New York: Viking Press.

Olivelle, Patrick. (2003). The Renouncer Tradition. In: Flood Gavin (ed.), The Blackwell Companion to Hinduism, pp. 271-287. Oxford, Blackwell Publishing.

Pinch, William R. (2006). Warrior Ascetics and Indian Empires (Cambridge Studies in Indian History and Society, 12). New York: Cambridge University Press.

Singh, Bhagat. (1930). Why I am an Atheist. [Online]. Retrieved on 20 July 2009 from: http://www.boloji.com/ spirituality/051.htm.

Tripathi, Govardhanram Madhavram (2007 [1887-1902]). Saraswatichandra. New Delhi: Sahitya Akademi.

Verma, Bhagwati Charan (1994 [1934]). Chitralekha. New Delhi: Rajkamal Prakashan.

\section{FILMOGRAPHY}

Adi Shankaracharya (1983). Dir. G. V. Iyer. Perf. Sarvadaman D. Banerjee and Bharat Bhushan. National Film Development Corporation of India.

Amrapali (1966). Dir. Lekh Tandon. Perf. Sunil Dutt and Vyjayanthimala. Eagle Films.

Angulimala (1960). Dir. Vijay Bhatt. Perf. Bharat Bhushan. Thai Information Service Co.

Anandmath (1952). Dir. Hemen Gupta. Perf. Prithviraj Kapoor, Ajit, Pradeep Kumar, and Geeta Bali. Filmistan.

Chitralekha (1964). Dir. Kidar Nath Sharma. Perf. Ashok Kumar, Pradeep Kumar, and Meena Kumari. Pushpa Pictures.

Devdas (1955). Dir. Bimal Roy. Perf. Dilip Kumar, Suchitra Sen, and Vyjayanthimala. Bimal Roy Productions.

Diksha (1991). Dir. Arun Kaul. Perf. Nana Patekar and Manohar Singh. Arun Kaul.

Do Ankhen Barah Haath (1957). Dir. and Perf. V. Shantaram. Rajkamal Kala Mandir.

Gautama the Buddha (1967). Dir. Bimal Roy. Film Division of India.

Guide (1965). Dir. Vijay Anand. Perf. Dev Anand and Waheeda Rehman. Navketan International Films.

The Guru (2002). Dir. Daisy Von Scherler Mayer. Perf. Marisa Tomei, Heather Graham, and Jimi Mistry. Universal Pictures.

The Householder (1963). Dir. James Ivory. Perf. Shashi Kapoor and Leela Naidu. Merchant Ivory Productions.

I Confess (1953). Dir. Alfred Hitchcock. Perf. Montgomery Clift and Anne Baxter. Warner Bros. Pictures.

Jaadugar (1989). Dir. Prakash Mehra. Perf. Amitabh Bachchan. Prakash Mehra Productions.

Jagadguru Shankaracharya (1955). Dir. Sheikh Fattelal.

Jagadguru Shrimad Shankaracharya (1928). Dir. and perf. Parshwanath Yeshwant Altekar.

Jogan (1950). Dir. Kidar Nath Sharma. Perf. Nargis and Dilip Kumar. Shree Ranjit Movitone Co.

The Love Guru (2008). Dir. Marco Schnabel. Perf. Mike Myers, Justin Timberlake, and Romany Malco. Paramount Pictures.

Madhvacharya (1987). Dir. G. V. Iyer. Perf. Poorna Prasad, G. M. Krishnamurthy, Hayagrivachar, G. V. Shivanand. Ananthalakshmi Films. 
Paap (2003). Dir. Pooja Bhatt. Perf. John Abraham and Udita Goswami. Fish Eye Network.

Prem Sanyas (aka die Leauchte Asiens and the Light of Asia) (1925). Dir. Franz Osten and Himanshu Rai. Great Eastern Film Corporation.

Samskara (1970). Dir. Pattabhi Rama Reddy. Perf. Girish Karnad. Ramamanohara Chitra.

Sanyasi (1975). Dir. Sohanlal Kanwar. Perf. Manoj Kumar and Hema Malini. Filmnagar.

Sara Akash (1969). Dir. Basu Chatterjee. Perf. Rakesh Pandey and Madhu Chakravarty. Cine Eye Films.

Saraswatichandra (1969). Dir. Govind Saraiya. Perf. Nutan and Manish. Sarvodaya Pictures.

Scarlet Letter (1995). Dir. Roland Joffé. Perf. Demi Moore and Gary Oldman. Allied Stars Ltd.

Shaheed (1965). Dir. S. Ram Sharma. Perf. Manoj Kumar. K.P.K. Movies.

Shankaracharya (1927). Dir. Kaliprasad Ghosh. Perf. Kanan Devi.

Siddhartha (1972). Dir. Conrad Rooks. Perf. Shashi Kapoor and Simi Grewal. Lotus Films.

Sins (2005). Dir. Vinod Pandey. Shiney Ahuja. Yashraj Films.

Swami Dada (1982). Dir. Dev Anand. Perf. Dev Anand. Deva Anand.

Swami Vivekananda (1949). Dir. Amar Mullick. Perf. Ajit Prakash. Amar Mullick Productions.

Trishagni (1994). Dir. Nabendu Gosh. Perf. Nana Patekar and Pallavi Joshi. Nabendu Gosh, 1998.

Vivekananda (1994). Dir. G. V. Iyer. Perf. Sadanand Bannerjee and Mithun Chakraborty. Ananthalakshmi Films.

Yehi Hai Zindagi (1977). Dir. K. S. Sethumadhavan. Perf. Sanjeev Kumar. Vijaya Productions Pvt. Ltd. 